\title{
PREVALENCE AND IDENTIFICATION OF COCCIDIAN PARASITE (EIMERIA SPP) IN LAYER CHICKEN OF RATNANAGAR MUNICIPALITY, CHITWAN DISTRICT, NEPAL
}

\author{
A. Adhikari, R. Gupta and G. R. Pant
}

\begin{abstract}
Five different species of Eimeria viz. E. acervulina, E. maxima, E. necatrix, E. tenella and E. brunetti were identified. The highest percentage (50\%) was found with mixed infection. Specieswise infection with $E$. tenella was recorded in the present study. Monthwise highest prevalence rate (50\%) was observed in March and the lowest (10\%) in the months of April and September. Seasonwise prevalence showed the highest prevalence rate $(33 \%)$ in the summer and spring, and the least (14\%) in the autumn. The agewise prevalence was the highest (48\%) in the 31-45 days age group and the least (6\%) in 0-15 days age group of layers. The coccidiosis was found highly prevalence in mud/mud+brick type floor than in concrete type floor farms.
\end{abstract}

Key words: Coccidiosis, Eimeria, infection, layers, percentage, summer, spring

\section{Introduction}

Coccidiosis is one of the most important diseases of chicken in Nepal. It is a protozoan disease caused by Eimeria species. On the basis of affecting organs, the disease is classified as intestinal coccidiosis affecting the small intestine and caecal coccidiosis affecting the large intestine (caeca). At least nine species of Eimeria are known to occur in poultry (Jordan and Pattison, 1996).

Coccidiosis is characterized by dysentery, enteritis, emaciation, drooping wings, poor growth and low production. In all parts of the world where confinement rearing is practiced, coccidiosis represents a major disease problem demanding attention of poultry producers, feed manufactures and poultry disease experts. The economic importance of the disease is due to its high rate of morbidity and mortality in young birds, reduced feed conversion efficiency and egg production in sub-clinical cases.

It is considered to be a disease of poor management. Indiscriminate use of anticoccidial drugs in feed and water has created serious drugs resistance problem. So, the study is essential for proper identification of different species of Eimeria and knowledge regarding the epidemiological conditions of prevalence of coccidiosis. This study will greatly help to develop control strategy against coccidiosis.

\section{Materials and Methods}

A total of 480 dropping samples of layer chicken were collected randomly from different floor system and farming system of poultry farms of Ratnanagar Municipality and its vicinity to determine the prevalence of coccidiosis from August 2002 to July 2003. For species 
identification twenty layer dead chickens were collected.

These dropping samples were examined by smear method and positive samples for coccidian parasites were cultured in $2 \%$ potassium dichromate solution at the ratio of 1:5. These sporulated oocysts were examined at low and high power objectives.

Postmortem examinations were carried out by the processes (a) necropsy examination (b) microscopic examination of mucosal scrapping. By postmortem examination, intestinal samples were collected and cultured. The sporulated oocysts of Eimeria species were stained by midified Ziehil-Neelsen technique for microscopic examination. At least 27 sporulated oocysts from each area of the intestinal tract (anterior, middle, posterior parts of small intestine and from the caecal pouches) were measured for their morphological characteristics (length, width and shape). The information collected from postmortem finding and findings of microscopic examination were compiled, analyzed with each other. The findings were verified by figures and description made by Gordon and Jordan (1982).

\section{Results}

1 General prevalence of coccidiosis

Out of 480 drooping samples examined, 125 samples were positive. This implies that prevalence of coccidiosis in layer was found to be $25 \%$.

2 Monthwise prevalence of coccidiosis

The highest prevalence rate of coccidiosis (50\%) was found in the month of March and the least $(10 \%)$ in the months of April and September. No droppings for coccidiosis were found in the months of November and December (Fig.1).

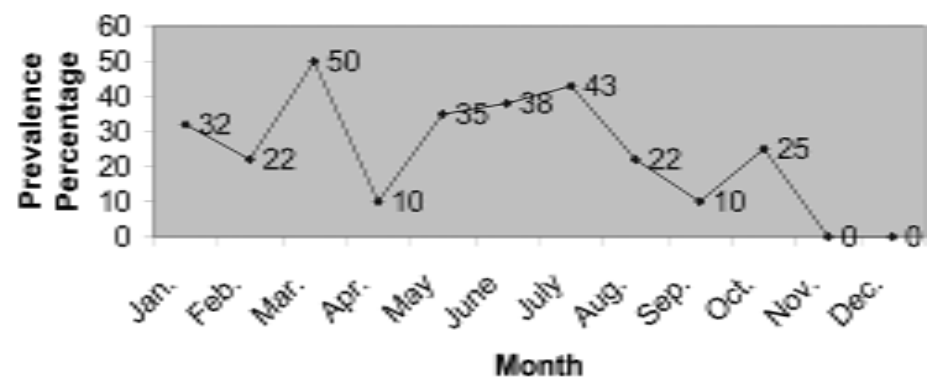

Fig. 1 Monthwise prevalence of cocciciosis 


\section{Seasonwise prevalence of coccidiosis}

The prevalence of coccidiosis was the highest (33\%) during summer and spring season followed by winter season (23\%) and the least (14\%) in autumn (Fig.2).

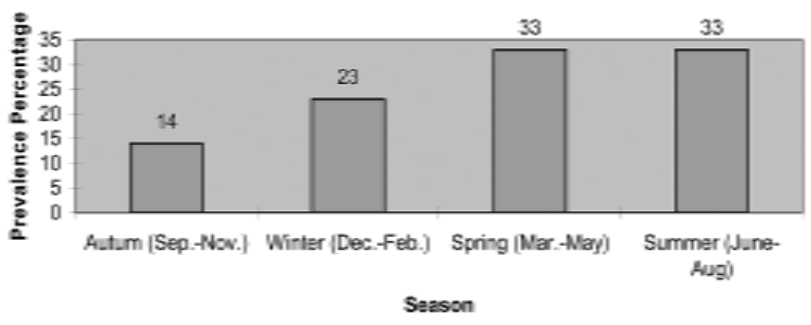

Fig.2 Seasonwise prevalence of coccidiosis

4 Agewise prevalence of coccidiosis

The age groups of studied flocks of layer were categorized into difference of 15 days. The Fig. 3 shows that the prevalence of coccidiosis was the highest (48\%) in 31-45 days and the least (6\%) in 0-15 day's layers. In 90 days above age group, the positive dropping samples for coccidiosis were not found at all.

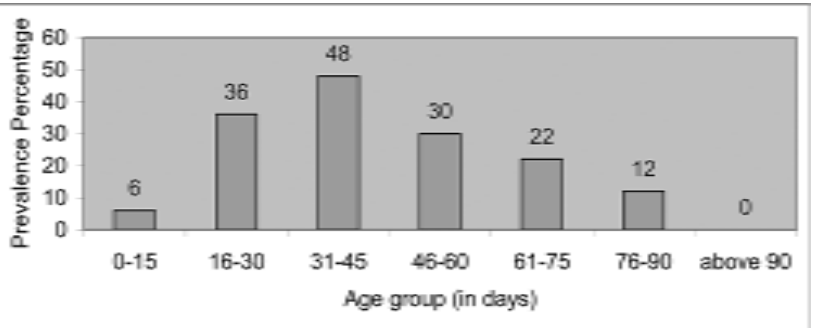

Fig.3 Agewise prevalence of Coccidiosis

5 Prevalence of coccidiosis in different floor types of farm

Out of 180 droppping samples of concrete type floor of layer chicken , (24\%) samples were positive and out of 260 dropping samples of mud/mud+brick type floor, (29\%) were positive for coccidiosis (Fig. 4).

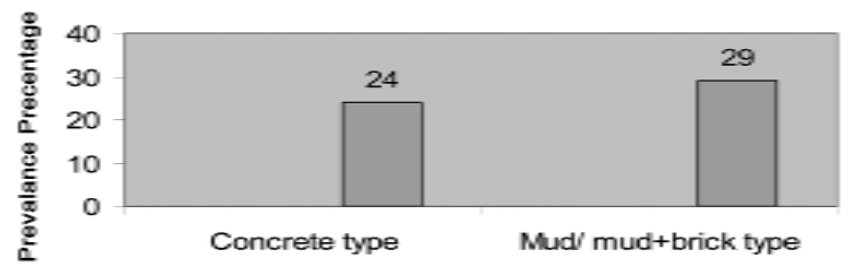

Fig: 4 Prevalence of coccidiosis in different floor systems. 


\section{Identification of Eimeria spp}

Table 1 shows that five different species of Eimeria were identified viz. E. acervulina, E.maxima, E. necatrix, E.brunetti and E. tenella. The observed postmortem lesions were distinct for all other species except E.maxima and E. necatrix. The calculated $Z$ values (1.61 and 1.95) for mean length and width for E.necatrix and E. tenella were less than tabulated value (1.96). So, there was no significant difference at $\mathrm{P}<0.05$ level of significance. The shape index often quoted as criteria for species identification but less variation was found in shape index of different species.

Table: 1 Identification of different species of Eimeria

\begin{tabular}{|c|c|c|c|c|c|c|}
\hline \multirow{3}{*}{$\begin{array}{l}\text { Intestinal part/ } \\
\text { location }\end{array}$} & \multirow{3}{*}{$\begin{array}{l}\text { Postmortem } \\
\text { lesions }\end{array}$} & \multicolumn{4}{|c|}{ Characteristics of oocysts } & \multirow{3}{*}{$\begin{array}{l}\text { Species of } \\
\text { Eimeria } \\
\text { identified }\end{array}$} \\
\hline & & \multicolumn{2}{|l|}{ Size $(\mu \mathrm{m})$} & \multirow{2}{*}{$\begin{array}{l}\text { Shape } \\
\text { index }\end{array}$} & \multirow[t]{2}{*}{ Shape } & \\
\hline & & $\begin{array}{l}\text { Mean Length } \\
\pm S D \text { (Range) }\end{array}$ & $\begin{array}{l}\text { Mean width } \\
\pm S D \text { (Range) }\end{array}$ & & & \\
\hline $\begin{array}{l}\text { Anterior small } \\
\text { intestine }\end{array}$ & $\begin{array}{l}\text { Transverse } \\
\text { Whitish band on } \\
\text { duodenal loop. }\end{array}$ & $\begin{array}{l}17.93 \pm 2.61 \\
(13.76-20.64)\end{array}$ & $\begin{array}{l}14.12 \pm 2.61 \\
(10.32-17.20)\end{array}$ & 1.27 & Ovoid & $\begin{array}{l}\text { E. } \\
\text { acervulina }\end{array}$ \\
\hline $\begin{array}{l}\text { Middle small } \\
\text { intestine }\end{array}$ & $\begin{array}{l}\text { Thickened } \\
\text { intestine wall. } \\
\text { Patechiae. }\end{array}$ & $\begin{array}{l}29.41 \pm 3.25 \\
(24.08-37.84)\end{array}$ & $\begin{array}{l}22.28 \pm 3.25 \\
(17.20-27.52)\end{array}$ & 1.32 & Ovoid & E. maxima \\
\hline $\begin{array}{l}\text { Middle small } \\
\text { intestine }\end{array}$ & $\begin{array}{l}\text { Balloning of } \\
\text { intestine. Mucoid } \\
\text { blood filled } \\
\text { exudates }\end{array}$ & $\begin{array}{l}20.10 \pm 2.6 \\
(17.20-24.08)\end{array}$ & $\begin{array}{l}16.32 \pm 2.43 \\
(13.76-20.64)\end{array}$ & 1.23 & $\begin{array}{l}\text { Oblong } \\
\text { Ovoid }\end{array}$ & E. necatrix \\
\hline Caeca & $\begin{array}{l}\text { Haemorrhages } \\
\text { and clotted blood } \\
\text { in caecal pouches }\end{array}$ & $\begin{array}{l}20.81 \pm 2.34 \\
(17.20-24.08)\end{array}$ & $\begin{array}{l}17.12 \pm 2.27 \\
(13.76-20.64)\end{array}$ & 1.21 & Ovoid & E. tenella \\
\hline $\begin{array}{l}\text { Posterior small } \\
\text { intestine }\end{array}$ & $\begin{array}{l}\text { Mucoid, Bloody } \\
\text { enteritis }\end{array}$ & $\begin{array}{l}23.75 \pm 2.85 \\
(20.64-27.52)\end{array}$ & $\begin{array}{l}19.52 \pm 1.98 \\
(17.52-24.08)\end{array}$ & 1.22 & Ovoid & E. brunetti \\
\hline
\end{tabular}

Mono and mixed infection of Eimeria species

Out of 20 positive cases of coccidiosis the highest prevalence (50\%) were found with mixed species infection. In case of mono species infection the incidence of $E$. tenella was found the highest $(25 \%)$ followed by E. necatrix (10\%), E. acervulina (5\%), E. brunetti $(5 \%)$ and E. maxima (5\%) (Fig.5).

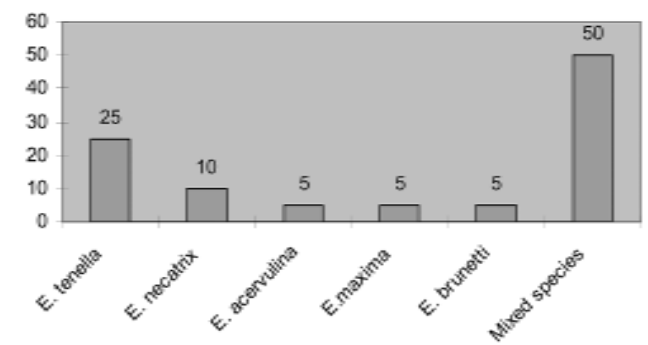

Fig.5 Mono and mixed infection of Eimeria species 


\section{Discussion and conclusion}

Coccidiosis disease is most likely when young stocks are concentrated under conditions which permit the accumulation and sporulation of large number of oocysts. In the present study, the general prevalence rate of coccidiosis was found to be $25 \%$. This was somewhat similar to the $38 \%$ farm level prevalence reported by Razmi et al. (2000) in Iran. Monthwise higher prevalence was found in the March and the lower (10\%) in both April and September. This high prevalence rate of coccidiosis might be due to effect of favourable environment for the sporulation of oocysts. Seasonwise prevalence rate of coccidiosis was the highest (33\%) during summer and spring, and the lowest (14\%) during autumn season. The prevalence of coccidiosis is higher in summer and spring season may be due to the hot and humid climate .Agewise prevalence of coccidiosis was found the highest in 31-45 days agegroup (48\%) and the least (6\%) in 0-15 days age group. The high prevalence of coccidiosis might be associated with crowding factor and the presence of high number of oocysts in the litter at 31-45 days. Hence, this age group might be very susceptible to coccidial infections. Hofstad (1992) reported that 3-6 weeks age group of chicken were very susceptible to coccidial infection.

Coccidiosis is the disease of poor management. The prevalence of coccidiosis was highest (29\%) in mud/mud+brick type floor than that in concrete type floor. This finding was somewhat similar with report mentioned by Farooq et al. (1999). They reported significantly higher mobidity (20.89 6.49\%) and mortality (8.86 $0.41 \%)$ in chicken reared on brick+mud made floors at the ground level than concrete type floors above the ground level morbidity (7.37 $1.47 \%)$, mortality (3.02 1.23\%). The lower prevalence of coccidiosis in concrete type floor might be due to effective eradication of Eimeria oocysts at the time of cleaning of floors. The higher prevalence of coccidiosis in mud/mud+brick type floors might be associated with more chances of coccdian oocysts to survive in the cracks and cervices of mud/mud+brick type floors, which may difficult for effective cleanliness of farms.

On the basis of biological characteristics, such as lesion seen, location and morphological characteristics, five species of Eimeria viz. E.tenella, E.acervulina, E.necatrix, E.maxima and E.brunetti were identified. It is similar to the report mentioned in Brazil by Franco (1993). These identified Eimeria species except E.necatrix have been reported earlier by Thakuri and Rai (1996) in the local chickens of eastern hills of Nepal . It is correlated to the report mentioned in Bangladesh by Karim and Begun (1994). The findings agree with the statement made by Macpherson (1978) that the same species of Eimeria all over the world will infect domestic poultry. The morphological characteristics, location and nature of intestinal lesions correspond to the description made by Gorden and Jordan (1982).

The highest prevalence of mixed Eimeria infection (50\%) was found. In case of mono species infection the incidence of $E$. tenella was found the highest (25\%). These results coincide with the findings of Aryal (2001). i.e mixed coccidial infection (64\%) and E.tenella (12\%). The highest prevalence of mixed species infection might be due to opportunistic nature of the mild pathogenic species of Eimeria i.e. E.maxima and E.acervulina which starts infection in the bird under sufficient stress due to initial infection with pathogenic species. The highest prevalence of E.tenella might be due to its highly pathogenic and predominant nature. 


\section{Acknowledgement}

This paper is based on a first author's research work, which was carried out for the partial fulfillment of the Master's Degree at the Central Department of Zoology, Tribhuvan University. Authors would like to thank to the Central Department of Zoology, T.U., Central Veterinary Laboratories, Tripureshwor, District Veterinary Service Office, Chitwan and National Avian Diagnostic Centre, Bharatpur. Sincere thanks goes to all the vetenarians, poultry farmers of Chitwan district and friends involved in this study.

\section{References}

Aryal M.P. (2001). Epidemiological study on Eimeria species in natural outbreak of chicken coccidiosis at IAAS Rampur and its vicinity. Advances in Agriculture Research in Nepal at Society of Agriculture Scientists (AAS), Nepal: 168-175.

Farooq, M., Durranil, F.R., Waheedullah, W., Sajjad, A. and Asghar, A. (1999). Prevalence of coccidiosis in broilers in the subtropical environment http/www.priory.com/vet/broolers.htm.

Franco, R.M.B. (1993). Survey of avain coccidioosis from two layers poultry farms in Campinas, Brazil, Arquivo Brasileiro de Medicina Veterinaria zootechia, 45(6): 557-571.

Gorden R.F. and Jordan, F.T.W. (1982) . Poultry Diseasea. Second Edition. Bailliere Tindall: 169-177.

Hofstad, M.S. (1992). Diseases of Poultry. Eighth edition 1st Indian reprint, Parima educational book agency, New Delhi: 691-708.

Jordan, F.T.W, and Pattison, M. (1996). Poultry Diseases, Fourth Edition, W.B. Sunders company Ltd., London NW 19 DFX.

Karim, M. J and Begun, N. (1994). Morphological and biological characterization of chicken Eimeria with special reference to species identification. Vet. Review Pakhribas Agriculture Centre (PAC). 9(1) and 10(1):7-9.

Macperson, I. (1978). Avain Coccidiosis, British Poultry Science Ltd., Edinburgh, Scotaland: 465-494.

Razmi, R.G. and Likalideri, G.A.(2000). Prevalence of subclinical coccidiosis in broiler chicken farms in municipality of Mashhad, Karason, Iran. Veterinary Medicine, 44(314): 247-253.

Thakuri, K.C. and Rai, K. (1996). Identification of Eimeria species found in local chicken of eastern hills of Nepal. Veterinary Review, 9 (1):5-6, Pakhribas Agriculture Centre, Dhankutta, Nepal.

\section{Author's Address}

${ }^{1}$ Arjun Adhikari, ${ }^{2}$ Dr. Ranjana Gupta and ${ }^{3}$ Dr. Ganesh Raj Pant

${ }^{1}$ Food Quarantine Laboratory, Birganj, E-mail: arjunadh2000@yahoo.com

${ }^{2}$ Central Department of Zoology, T.U. Kirtipur, Kathmandu

${ }^{3}$ Central Veterinary Laboratory, Tripureshwor, Kathmandu 